\title{
Changes in the Prevalence of Coccidian Protozoa in Immunocompromised Patients Over the Last Decade
}

\author{
Bağışıkı̆̆ı Baskılanmış Hastalarda Koksidian Protozoon Prevalansının Son On Yıldaki \\ Değişimi
}

\author{
๑ Özlem ULUSAN BAĞCI ${ }^{1}$, ๑ Orçun ZORBOZAN ${ }^{1}$, ๑ Kardelen YETişMiş² ${ }^{2}$ ๑ Sema AYDOĞDU ${ }^{3}$, ๑ Fatma Ömür ARDENiZ ${ }^{4}$,

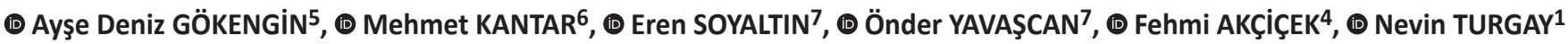 \\ ${ }^{1}$ Ege University Faculty of Medicine, Department of Parasitology, Izmir, Turkey \\ ${ }^{2}$ Ege University Institute of Health Sciences, Izmir, Turkey \\ ${ }^{3}$ Ege University Faculty of Medicine, Department of Pediatric Gastroenterology, Izmir, Turkey \\ ${ }^{4}$ Ege University Faculty of Medicine, Department of Internal Medicine, izmir, Turkey \\ ${ }^{5}$ Ege University Faculty of Medicine, Department of Infectious Diseases and Clinical Microbiology, Izmir, Turkey \\ ${ }^{6}$ Ege University Faculty of Medicine, Department of Pediatric Health and Diseases, izmir, Turkey \\ 7University of Health Sciences Turkey, Tepecik Training and Research Hospital, Clinic of Pediatric Nephrology, Izmir, Turkey
}

\section{Abstract}

Introduction: Coccidian protozoal infection is one of the most important causes of diarrhea, which could prove to be fatal in immunosuppressed patients. The present study aimed to determine changes in the incidences and prevalence of coccidian protozoa in immunocompromised patients in two different time frames, and thus draw attention toward these neglected microorganisms.

Materials and Methods: The present study involved retrospective analysis of 311 stool samples obtained from 311 immunocompromised patients, collected over two time frames (2009 and 2016-2019).

Results: The study included 40.5\% female and 37.6\% pediatric immunocompromised patients (aged 0-18 years). In 2009, the incidences of Cryptosporidium spp. were $51.4 \%$ and this decreased to $41.6 \%$ in 2016-2019. Cyclospora spp. incidences decreased from $24.6 \%$ in 2009 to $9.8 \%$ in 2016-2019. Coccidian infection in pediatric patients was found to decrease over the stipulated time, where Cryptosporidium spp. incidences decreased from 63.9\% to 34.6\% and Cyclospora spp. detection rate decreased from 30.6\% to 4.9\%. In adults, detection rate for Cryptosporidium spp. changed from 47\% to 47.8\%, while Cyclospora spp. incidences changed from $22.5 \%$ to $14.1 \%$, over the period of 10 years.

Conclusion: The study demonstrated no significant changes in coccidian parasitic detection rates in immunocompromised adults over the period of 10 years, which remained high. However, a significant decrease in the detection rates of both Cryptosporidium and Cyclospora spp. was reported in pediatric patients over the years. A comparison with previously reported data revealed higher detection rates of coccidian parasite in immunocompromised patients as compared to the general patient population. These results also highlighted the importance of detailed patient information, especially clinical diagnosis and drug usage, to ensure application of appropriate diagnostic methods for laboratory evaluation of the stool samples obtained from immunocompromised patients. This will further aid in early diagnosis and management of such infections.

Keywords: Cryptosporidium, Cyclospora, coccidian, immunocompromised pediatric patients, infectious diarrhea

\section{Öz}

Giriş: Diyarenin önemli nedenlerinden olan koksidian protozoon enfeksiyonları bağışıklık sistemi baskılanmış hastalarda ölümcül seyredebilmektedir. Bu çalışmada bağışıklık sistemi baskılanmış hastalarda koksidian protozoon insidans ve prevalansının yıllar içerisindeki değişimini incelemek ve ihmal edilmiş bu etkenlere dikkat çekmek amaçlanmıştır.

Cite this article as: Ulusan Bağcı Ö, Zorbozan 0 , Yetişmiş K, Aydoğdu S, Ardeniz FÖ, Gökengin AD, Kantar M, Soyaltın E, Yavaşcan Ö, Akçiçek F, Turgay N. Changes in the Prevalence of Coccidian Protozoa in Immunocompromised Patients Over the Last Decade. Mediterr J Infect Microb Antimicrob. 2021;10:30. 
Gereç ve Yöntem: Çalışmamızda iki farklı zaman aralığında (2009 ve 2016-2019) toplanmış 311 hastaya ait 311 dışkı örneğinin sonuçları geriye dönük olarak değerlendirilmiştir.

Bulgular: Çalışmaya dahil edilen hastaların \%40,5'i kadın, \%37,6'sı çocuktur (0-18 yaş). Hastaların hepsinin bağışıklık sistemi baskılanmıştır. Cryptosporidium spp. saptanma oranı 2009 yılında \%51,4, 2016-2019 yılları arasında ise \%41,6 bulunmuştur. Cyclospora spp. görülme oranı ise 2009 yılında \%24,6'dan 2016-2019 yılları arasında \%9,8'e gerilemiştir. Çocuk hastalarda her iki koksidian protozoa enfeksiyon sıklığında azalma görülmüş, Cryptosporidium spp. prevalansı \%63,9'dan \%34,6'ya, Cyclospora spp. görülme oranı \%30,6'dan \%4,9'a gerilemiştir. Erişkin hastalarda Cryptosporidium spp. insidansı \%47'den \%47,8'e, Cyclospora spp. görülme oranı \%22,5'ten \%14,1'e değişmiştir.

Sonuç: Bu çalışma, koksidian parazit saptanma oranlarının erişkinlerde on yıl içinde anlamlı bir değişim göstermediğini ve yüksek seyrettiğini, ancak çocuklarda, hem Cryptosporidium spp. hem de Cyclospora spp. saptanma oranlarında yıllar içinde anlamlı bir düşüş gözlendiğini ortaya koymuştur. Çalışmamızın sonuçları, diğer çalışmalarda belirtilen oranlarla karşılaştırıldığında bağışıklığı baskılanmış hastalarda koksidian parazit saptama oranlarının genel hasta popülasyonuna göre daha yüksek olduğu görülmüştür. Sonuçlar, bağışıklığı baskılanmış bir hastada ishal geliştiğinde, hastanın özellikle klinik tanı ve ilaç kullanım bilgisini de içeren detaylı bir bilgi notu gönderilmesinin önemini vurgulamaktadır. Bu yaklaşım, dışkı örneğine laboratuvarlar tarafından gerekli tüm yöntemlerin uygulanmasını sağlayacak erken tanı ve tedavi başarısının artmasına katkıda bulunacaktır.

Anahtar Kelimeler: Cryptosporidium, Cyclospora, koksidian, bağışıklığı baskılanmış çocuk hastalar, enfeksiyöz diyare

\section{Introduction}

Recent times have witnessed a significant increase in the number of immunocompromised individuals, majorly due to frequent use of immunosuppressive drugs and increase in the incidences and prevalence of human immunodeficiency virus (HIV) infection worldwide. Despite the medical advancement, opportunistic infections, particularly those associated with diarrhea, remain a major challenge in the management of immunocompromised patients ${ }^{[1-4]}$. The frequency of infectious diarrhea is reported to be $\sim 20-50 \%$ in such patients. However, these values might vary depending upon the population under study and type of diagnostic method employed for evaluation $^{[5]}$. A variety of microorganisms, including bacteria, viruses, and parasites, have been reported to cause diarrhea in immunocompromised patients. Among these, coccidian protozoa such as Cystoisospora belli, Cryptosporidium spp., and Cyclospora spp. are the key players responsible for diarrhea in these patients. These parasites are generally self-limiting in immuno-competent patients ${ }^{[6]}$; however, these can cause chronic and persistent diarrhea, malabsorption of nutrients, dehydration, and weight loss in immunocompromised patients ${ }^{[3]}$. In fact, they can prove to be fatal in such cases $^{[7]}$. Besides this, these coccidian protozoa might lead to severe clinical manifestations such as cholecystitis, cholangitis, pancreatitis, and respiratory cryptosporidiosis in immunocompromised patients. Since cellular immunity is not fully developed in children, the incidences of severe diarrhea might cause delay in growth and development. In certain pediatric patients, coccidian parasites might result in fatal infections, arising due to hypovolemic shock and cardiac deficiency that are primarily attributed by dehydration ${ }^{[8]}$. Diarrhea is the second leading cause of death among children under the age of five. Globally, it accounts for $11 \%$ of the pediatric deaths ${ }^{[9]}$. Diarrhea associated with Cryptosporidium and Cystoisospora infections is an AIDSdefining condition that might result in death if undiagnosed ${ }^{[10]}$.
Laboratory diagnosis of coccidian protozoa poses a serious challenge as direct microscopic examination and trichrome staining based detection methods are insufficient. Use of special staining methods, direct fluorescent antibody methods or molecular methods, which are not routinely used in the laboratory, is required to overcome this barrier ${ }^{[11]}$. However, in case of immunocompromised patients, such as HIV-infected and AIDS patients, individuals under corticosteroid therapy (receiving dosage of 5-20 mg/day depending on severity), organ transplantation cases, and the ones receiving chemotherapy, the detection of these infectious agents using appropriate method might be life-saving.

The present study aimed to determine the prevalence of coccidian protozoa in immunocompromised patients in two different timeframes, and thus define any changes in the infection trends with time.

\section{Materials and Methods}

The study was conducted in accordance to the Helsinki Declaration Ethical Standards (2008 principles). All the experimental procedures included in the study were approved by Ege University Ethics Committee for Medical Research (dated: 24/09/2020, number: 20-9T/68).

The present study involved a retrospective analysis of the laboratory results obtained for stool samples collected from immunocompromised patients, who were suffering from diarrhea and referred for microscopic examination. Samples collected at two time periods (2009 and the period between January 2016 and December 2019) were included for comparison. Patients aged 0-18 years were defined as children, while those with age $\geq 19$ were regarded as adults.

Clinical information about the patients was obtained from the laboratory request forms forwarded by the relevant clinics. Samples with missing information like patient name, referring 
service, clinical diagnosis, and time of receipt were excluded from the study. Only one repetitive stool sample from the same patient was included in the study and in the case of positivity, the positive sample was selected. The cases were divided into five main groups, namely immunodeficiency [common variable immunodeficiency, severe combined immunodeficiency, HIV (+) or AIDS], organ or bone marrow transplantation, cancer, steroid users, and others, on the basis of their clinical diagnosis.

For immunocompromised patients, the routine examination of stool samples at the Parasitology Department involved use of macroscopic examination, direct microscopic examination in saline and iodine, the modified formol-ethyl acetate precipitation method, and four different staining method involving Kinyoun acid-resistant stain, acid-resistant trichrome staining for Cryptosporidium spp., Cyclospora spp., C. belli, modified trichrome, and giemsa staining for Microsporidia ${ }^{[11]}$. The stained slides were screened for the presence of coccidian protozoa under 1000X magnification by at least two experienced specialists.

\section{Statistical Analysis}

The resulting data were analyzed using Statistical Package for Social Sciences 18 software. Pearson's chi-square test was used to compare the $\%$ coccidian parasites present in immunosupressed patients for two timeframes. For statistical analysis, $p$ value $\leq 0.05$ was considered to be significant.

\section{Results}

The present study involved retrospective screening of the laboratory records obtained for 337 stool samples collected from immunocompromised patients, referred for laboratory analysis, during the specified timeframes. However, three samples with missing data and 23 repetitive samples obtained from same patients were excluded from the study. The results for the remaining 311 stool samples collected from 311 immunocompromised patients (only one sample per patient) were analyzed. Among these, 138 and 173 results belonged to 2009 and 2016-2019 timeframes, respectively. The study group included $40.5 \%$ females and $37.6 \%$ pediatric cases. For all patients, diarrhea was the main complaint, caused by microorganisms, drug use, malabsorption, radiation, food allergies or intolerance. The stool samples for the patients were examined for coccidian protozoa using four different staining methods. The distribution of the patients and parasites according to the clinical diagnosis is summarized in Table 1.

The staining results for the samples collected in 2009 showed the presence of Cryptosporidium spp. and Cyclospora spp. in $51.4 \%(71 / 138)$ and $24.6 \%(34 / 138)$ samples, respectively. For the time period 2016-2019, Cryptosporidium spp. was found in
41.6\% (72/173) samples, while 9.8\% (17/173) samples tested positive for Cyclospora spp. These results suggested a reduction in the detection rate of both parasites over time; however, this reduction was found to be signicant only for Cyclospora spp. $(p \leq 0.05)$. Interestingly, $C$. belli was detected in only one pediatric patient belonging to the time frame 2016-2019, thus no comparison could be made between its detection rates in two groups.

For pediatric patients, a significant decrease in the detection rate was observed for both Cryptosporidium and Cyclospora spp. $(\mathrm{p} \leq 0.05)$. Cryptosporidium spp. detection rate decreased from $63.9 \%$ in 2009 to $34.6 \%$ in $2016-2019$. Similarly, the detection of Cyclospora spp. decreased from 30.6\% in 2009 to $4.9 \%$ in 2016-2019. For adult patients, the detection rate for Cryptosporidium spp. increased by only $0.8 \%$ between the two groups ( $p>0.05$ ). In comparison to this, a significant decrease in Cycplospora spp. detection was observed over time, where $22.5 \%$ and $14.1 \%$ detection rates were reported in 2009 and $2016-2019$, respectively $(p>0.05)$. The changes in the detection rate of Cryptosporidium spp. and Cyclospora spp. within the stipulated time interval of a decade are summarized in Figure 1.

The comparative analysis for the patient goups from two time frames showed a decrease in the detection rate of coccidian parasites in all groups, irrespective of the clinical diagnosis. However, this decrease was found to be statistically significant only in cancer group $(\mathrm{p} \leq 0.05)$. The microscopic images for Cryptosporidium and Cyclospora spp. oocysts present in the

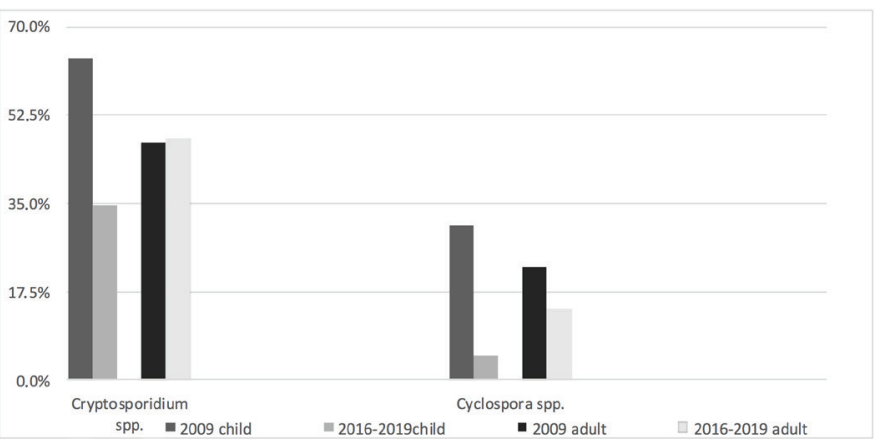

Figure 1. The change in the detection rates of Cryptosporidium and Cyclospora spp. within the time interval of one decade
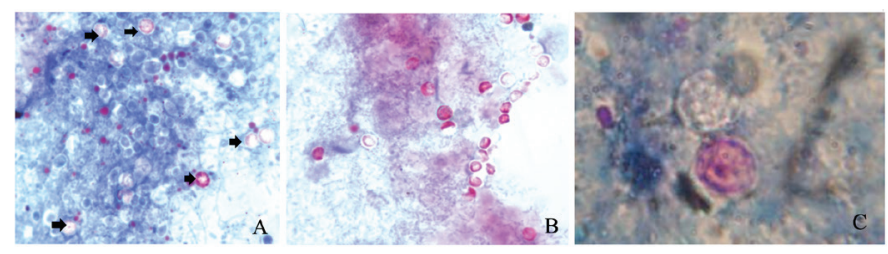

Figure 2. The microscopic images for (A) and (B) Cryptosporidium and (C) Cyclospora spp. oocysts for the samples evaluated in our laboratory (at 1000X magnification) 
Table 1. The distribution of the patients and parasites according to the clinical diagnosis, for the two time frames

\begin{tabular}{|c|c|c|c|c|}
\hline \multirow[b]{2}{*}{ Clinical diagnosis } & \multicolumn{2}{|l|}{2009} & \multicolumn{2}{|l|}{ 2016-2019 } \\
\hline & $\begin{array}{l}\text { Cryptosporidium spp. } \\
\text { N }(\%)\end{array}$ & $\begin{array}{l}\text { Cyclospora spp. } \\
\text { N (\%) }\end{array}$ & $\begin{array}{l}\text { Cryptosporidium spp. } \\
\text { N (\%) }\end{array}$ & $\begin{array}{l}\text { Cyclospora spp. } \\
\mathrm{N}(\%)\end{array}$ \\
\hline Immunodeficiency & $4(50)$ & $1(12.5)$ & $37(40.7)$ & $12(13.2)$ \\
\hline $\begin{array}{l}\text { Organ transplant/bone marrow } \\
\text { transplantation }\end{array}$ & $27(42)$ & $17(26.6)$ & $25(45.4)$ & $4(7.2)$ \\
\hline Cancer & $18(56.3)$ & $10(31.3)$ & $6(31.6)$ & 0 \\
\hline Steroid user & $21(63.6)$ & $6(18.2)$ & - & - \\
\hline Other & 1 & 0 & 4 & 1 \\
\hline Adult & $48(47)$ & $23(22.5)$ & $44(47.8)$ & $13(14.1)$ \\
\hline Pediatric & $23(63.9)$ & $11(30.6)$ & $28(34.6)$ & $4(4.9)$ \\
\hline Total & $71(51.4)$ & $34(24.6)$ & $72(41.6)$ & $17(9.8)$ \\
\hline
\end{tabular}

$\mathrm{N}$ : number

samples, evaluated in our laboratory, are shown in Figure 2.

\section{Discussion}

The present study aimed to evaluate the prevalence of coccidian infection in immunocompromised adult and pediatric patients, for the samples collected in 2009 and 2016-2019. The study reported higher prevalence of coccidian parasites in adults, with no significant changes in detection rates over the decade. In comparison to this, pediatric incidences of Cryptosporidium and Cyclospora spp. infection were found to decrease over the years.

Coccidian protozoa, Cryptosporidium spp., Cyclospora spp., and C. belli, are known to infect the digestive system of humans and animals. The fecal oocysts of these parasites are highly resistant to environmental conditions, physical and chemical inactivation, and are transmitted to humans via contaminated water and food ${ }^{[12]}$. Cryptosporidium spp. transmission is mainly mediated via contaminated water, while contaminated food is the major source for Cyclospora spp. ${ }^{[12]}$. Since these oocysts are characterized by small diameter, they can easily pass through the filters with large pore size, and thus can survive in puddles for long time owing to slow sedimentation rate ${ }^{[13]}$. Among the 27 morphologically indistinguishable species of Cryptosporidium spp., 20 species, predominantly Cryptosporidium hominis and Cryptosporidium parvum, are known to cause infections in humans ${ }^{[14,15]}$. In healthy individuals, such infections are usually self-limiting. In the patients with immunosuppression due to HIV/AIDS infection, organ transplantation, chemotherapy, and corticosteroid use, these parasites can cause severe clinical manifestations such as diarrhea, weight loss, dehydration, and sometimes death ${ }^{[16]}$.

The prevalence of coccidian protozoans has been previosuly studied in different patient groups and a low detection rate of $1.4 \%$ was reported for Cryptosporidium spp. in $\operatorname{Iran}^{[17]}$. In separate studies conducted at our center at two different time frames, the detection rates were $6.8 \%$ and $7.5 \% \%^{[18,19]}$. Several other studies involving different regions of Turkey also reported lower detection rates of $0-14 \% 0^{[20-23]}$. However, significantly higher detection rates (6.1-61.1\%) have been reported in immunocompromised patients ${ }^{[20-23]}$, with $32.21 \%$ detection rate in HIV-positive cases ${ }^{[24]}, 21-50 \%$ in cases involving organ transplantation ${ }^{[25,26]}$, and $11.1 \%$ in acute myeloid leukemia ${ }^{[17]}$. These variations might be attributed to differences in the distribution of coccidian parasites in the environment of different regions, characteristics of the patient group or methods used for evaluation.

The diagnosis of coccidian protozoa is challenging and requires use of special staining methods. Since the excretion of parasitic oocysts is intermittent with low concentrations ${ }^{[27]}$, use of stool enrichment techniques, such as the precipitation method, increases the sensitivity of the diagnostic method. Additionally, examination of four separate preparations for one patient reduces the possibility of overlooking the parasite even in case of low numbers. The use of different staining methods facilitates the identification of the parasites that might show different staining patterns. Since these methods are not employed in daily routine, it might result in overlooking of some parasites, and thus contribute to the observed variability in results obtained from different facilities.

Limited knowledge is available for Cyclospora spp. as compared to Cryptosporidium spp., and it is mostly contributed by case reports. In fact, prevalence of this parasite has been addressed in very few studies. Previous studies from Turkey have reported lower detection rates for Cyclospora spp., with 1.29\% infection in malnourished children, $3.1 \%$ in HIV-positive adults ${ }^{[28,29]}$, and $1.4 \%$ in general patient population ${ }^{[18]}$.

The present study was conducted at the Parasitology Department of the Ege University hospital that monitors one of the largest HIV cohorts in Turkey; besides immunosuppressive drugs are 
commonly prescribed over here for organ transplantation and rheumatological diseases. The parasitology laboratory is highly experienced in the diagnosis of coccidian parasites and all diagnostic procedures included in the study are performed routinely for immunosuppressed patients. Thus, all these features might have resulted in higher detection levels reported in the present study as compared to other studies conducted in Turkey.

Although a significant decrease was reported in the coccidian parasite detection rates over the years, the reduction in Cyclospora spp. was more evident in pediatric cases. However, no such decrease was reported in the number of immunosuppressed pediatric cases in the last decade, and thus no specific reason could be identified for this reduction. Additionally, the transmission of Cyclospora spp. is mainly mediated via water or fruits, such as raspberries, blackberries, and strawberries, contaminated with sporulated oocysts ${ }^{[30]}$. A recent study from Turkey reported common occurrence of allergies from food, including strawberries, among children using immunosuppressive drugs, which might have resulted in lower consumption of such food items ${ }^{[31]}$.

The routine use of detailed diagnostic methods for all patients is majorly limited by the associated cost and use of labor-intensive and time-consuming procedures. Thus, it is important to specify the clinical diagnosis in the laboratory requisition form to ensure use of specific procedures by the laboratory personnel. To avoid false-negative outcomes, all laboratory personnel must be trained to perform enrichment process, specific staining methods, and microscopic evaluation of the preparations.

There has been a continuous increase in the prevalence of HIVpositive individuals in several parts of Europe, including Turkey. In Turkey, 25,809 HIV/AIDS cases were reported by the end of November 2020. In the last decade, HIV incidences increased by more than 2.5\% during 2012-2016. Poland, Turkey, and Romania accounted for more than $70 \%$ of the total cases reported in Central Europe during 2005-2014 ${ }^{[32,33]}$. Besides this, mathematical modeling studies also predicted that Turkey would experience $\sim 3$-fold increase in annual HIV cases as compared to the previously reported data ${ }^{[34]}$. In Turkey, $~ 50 \%$ of the new cases are still diagnosed at the later stages of the disease, indicating possibility of higher incidences of coccidian parasites ${ }^{[35,36]}$. Additionally, frequent use of various immunosuppressive drugs in the treatment of several other diseases, particularly in organ transplantation, cancer, and rheumatological diseases ${ }^{[3]}$, is indicative of higher risk of coccidian infection in such cases.

The present study was associated with certain limitations, including retrospective nature of the study, lack of detailed information regarding the clinical characteristics of the patients, and limited timeframe used for comparative analysis. In addition to these, no patient with corticosteroid use was referred to the laboratory in the second time period. Since the hospital handles many cases with malignancy or rheumatologic conditions that require corticosteroid use, this could be possibly attributed by absence of information regarding steroid use in the laboratory request form. However, considering the paucity of the national data for intestinal pathogens infecting immunocompromised hosts, the findings of the present study are valuable addition to the available literature in Turkey.

\section{Conclusion}

The present study reported no significant changes in coccidian infections in immunocompromised adult patients over the last decade. However, pediatric incidences of Cryptosporidium and Cyclospora spp. decreased over time. The results of the study highlighted the importance of detailed diagnostic methods, skilled laboratory personnel, and detailed patient information on requisition form, especially clinical diagnosis and drug usage, in early diagnosis and management of coccidian infection in immunocompromised patients.

\section{Acknowledgment}

We thank Atilla Atasever for his help in statistics.

\section{Ethics}

Ethics Committee Approval: All the experimental procedures included in the study were approved by Ege University Ethics Committee of Medical Research (dated: 24/09/2020, number: 20-9T/68).

Informed Consent: Retrospective study.

Peer-review: Externally and internally peer-reviewed.

\section{Authorship Contributions}

Surgical and Medical Practices: Ö.U.B., O.Z., K.Y., S.A., F.Ö.A., A.D.G., M.K., E.S., Ö.Y., F.A., N.T., Concept: Ö.U.B., Design: Ö.U.B., Data Collection or Processing: Ö.U.B., K.Y., S.A., F.Ö.A., A.D.G., M.K., E.S., Ö.Y., F.A., Analysis or Interpretation: Ö.U.B., O.Z., A.D.G., N.T., Literature Search: Ö.U.B., A.D.G., N.T., Writing: Ö.U.B., O.Z., K.Y., S.A., F.Ö.A., A.D.G., M.K., E.S., Ö.Y., F.A., N.T.

Conflict of Interest: No conflict of interest was declared by the authors.

Financial Disclosure: The authors declared that this study received no financial support.

\section{References}

1. Low A, Gavriilidis G, Larke N, B-Lajoie MR, Drouin O, Stover J, Muhe L, Easterbrook P. Incidence of opportunistic infections and the impact of antiretroviral therapy among hiv-infected adults in low- and middleincome countries: a systematic review and meta-analysis. Clin Infect Dis. 2016;62:1595-603. 
2. Kashyap A, Singh MP, Madhu, Ghoshal U. Occurrence of gastrointestinal opportunistic parasites in immunocompromised patients in Northern India. J Biol. 2013;1:77-80.

3. Stark D, Barratt JLN, van Hal S, Marriott D, Harkness J, Ellis JT. Clinical significance of enteric protozoa in the immunosuppressed human population. Clin Microbiol Rev. 2009;22:634-50.

4. Logan C, Beadsworth MB, Beeching NJ. HIV and diarrhoea: what is new? Curr Opin Infect Dis. 2016;29:486-94.

5. Santoiemma PP, Ison, MG, Angarone M. Newer approaches in diagnosis of diarrhea in immunocompromised patients. Curr Opin Infect Dis. 2019;32:461-7.

6. Ahmed SA, Karanis P. Cryptosporidium and Cryptosporidiosis: The Perspective from the Gulf Countries. Int J Env Res Public Health. 2020;17:6824.

7. Taye $B$, Desta $K$, Ejigu $S$, Dori GU. The magnitude and risk factors of intestinal parasitic infection in relation to human immunodeficiency virus infection and immune status, at Alert hospital, Addis Ababa, Ethiopia. Parasitol Int. 2014;63:550-6.

8. Liu L, Johnson HL, Cousens S, Perin J, Scott S, Lawn JE, Rudan I, Campbell H, Cibulskis R, Li M, Mathers C, Black RE, Child Health Epidemiology Reference Group of WHO and UNICEF. Global, regional, and national causes of child mortality: an updated systematic analysis for 2010 with time trends since 2000. Lancet. 2012;379:2151-61.

9. Center for Disease Control and Prevention. Last accessed date: 2021 March 11. Available from: https://www.cdc.gov/healthywater/global/householdwater-treatment.html

10. Center for Disease Control and Prevention. AIDS-defining conditions. Morbidity and Mortality Weekly Report. 2008;57:9.

11. Turgay N. Special Staining Tecniques. In: Korkmaz M, Ok ÜZ (eds). Laboratory in parasitology. Izmir: Turkish Society for Parasitology, 2011:37-40.

12. Bilung LM, Tahar AS, Yunos NE, Apun K, Lim YAL, Nillian E, Hashim HF. Detection of Cryptosporidium and Cyclospora Oocysts from Environmental Water for Drinking and Recreational Activities in Sarawak, Malaysia. Biomed Res Int. 2017;2017:4636420.

13. Betancourt W. Cryptosporidium spp. In: Rose JB, Jiménez-Cisneros B (eds). Water and sanitation for the 21st century: health and microbiological aspects of excreta and wastewater management (Global Water Pathogen Project). UNESCO: Michigan State University, 2019.

14. Ryan UN, Fayer R, Xiao L. Cryptosporidium species in humans and animals: current understanding and research needs. Parasitol. 2014;141:1667-85.

15. Ryan U, Xiao L. Taxonomy and molecular taxonomy. In: Simone MC, Giovanni W (eds). Cryptosporidium: parasite and disease. Vienna: Springer. 2014:3-41.

16. Gerace E, Lo Presti VDM, Biondo C. Cryptosporidium infection: Epidemiology, pathogenesis, and differential diagnosis. Eur J Microbiol Immun (Bp). 2019;9:119-23.

17. Nahrevanian H, Assmar M. Cryptosporidiosis in immunocompromised patients in the Islamic Republic of Iran. J Microbiol Immunol Infect. 2008;41:74-7.

18. Ulusan Ö, Zorbozan O, Yetişmiş K, Töz S, Ünver A, Turgay N. The distribution of the intestinal parasites detected in ege university medical faculty parasitology direct diagnosis laboratory; 10-years evaluation. Journal of Turkish Microbiological Society. 2019;49:86-91.

19. Turgay N, Ünver-Yolasığmaz A, Oyur T, Bardak-Özcem S, Töz S. Monthly Distribution of Intestinal Parasites Detected in a Part of Western Turkey between May 2009-April 2010-results of acid fast and modified trichrome staining methods. Acta Parasitologica Turcica. 2012;6:71-4.
20. Arıkan S, Ergüven $S$, Akyön $Y$, Günalp A. Cryptosporidiosis in immunocompromised patients in a Turkish University Hospital. Acta Parasitol Microbiol Hungarica. 1999;46:33-40.

21. Ok ÜZ, Kavaklı K, Çetingül N. Frequency of intestinal parasites among immunosuppressed patients undergoing chemotherapy. Acta Parasitologica Turcica. 1995;20:385-90.

22. Tanyuksel $\mathrm{M}$, Haznedaroğlu T, Gün H. Investigation of Cryptosporidium in neoplastic patients. Acta Parasitologica Turcica. 1995;19:56-63.

23. Yıldız M, Çöplü N, Kılıç S, Babür C, Öncül Ö, Esen B. Investigation of Cryptosporidium spp. in solid tumor cases with diarrhea. Acta Parasitologica Turcica. 2001;25:8.

24. Hunter PR, Nichols G. Epidemiology and clinical features of Cryptosporidium infection in immunocompromised patients. Clin Microbiol Rev. 2002;15:145-54.

25. Raja K, Abbas Z, Hassan SM, Luck NH, Aziz T, Mubarak M. Prevalence of cryptosporidiosis in renal transplant recipients presenting with acute diarrhea at a single center in Pakistan. J Nephropathol. 2014;3:127-31.

26. Arslan H, Inci EK, Azap OK, Karakayali H, Torgay A, Haberal M. Etiologic agents of diarrhea in solid organ recipients. Transpl Infect Dis. 2007;9:2705.

27. Garcia LS, Arrowood M, Kokoskin E, Paltridge GP, Pillai DR, Procop GW, Shimizu RY, Visvesvara G. Laboratory diagnosis of parasites from the gastrointestinal tract. Clin Microbiol Rev. 2017;31:e00025-17.

28. Osman GA, Makled KM, El-Shakankiry HM, Metwali DM, Abdel-Aziz SS, Saafan $\mathrm{HH}$. Coccidian parasites as a cause of watery diarrhea among protein energy malnourished and other immunocompromised Egyptian children. J Egypt Soc Parasitol. 1999;29:653-68.

29. Zorbozan O, Quliyeva G, Tunalı V, Özbilgin A, Turgay N, Gökengin AD. Intestinal Protozoa in HIV-Infected Patients: A Retrospective Analysis. Acta Parasitologica Turcica. 2018; 42:187-90.

30. Centers for Disease Control and Prevention. Last Accessed Date: 18.06.2020. Available from: https://www.cdc.gov/parasites/cyclosporiasis/epi.html

31. Arikan C, Kilic M, Tokat Y, Aydogdu S. Allergic disease after pediatric liver transplantation with systemic tacrolimus and cyclosporine a therapy. Trans Proceed. 2003;35:3039-41.

32. Gökengin D. HIV infection in Turkey: How close are we to the target? Klimik Journal. 2018;31:4-10.

33. Gökengin D, Oprea C, Uysal S, Begovac J. The growing HIV epidemic in Central Europe: a neglected issue? J Virus Erad. 2016;2:156-61.

34. Yaylalı E, Gökengin D, Korten V, Tabak, Ünal S, Erdogan Z, Çalışır F, Özelgün $B$ and Sahin T. Modelling the future of HIV in Turkey: disease implications of improving prevention, diagnosis and treatment (Poster Presentation). HIV Drug Therapy Glasgow Virtual 2020 October 5-8. Online Congress; 2020;23:P114.

35. Erdinc FS, Dokuzoguz B, Unal S, Komur S, Inkaya AC, Inan D, Karaoglan I, Deveci A, Celen MK, Kose S, Erben N, Senturk GC, Heper Y, Kutlu SS, Hatipoglu CA, Sumer S, Kandemir B, Sirmatel F, Bayindir Y, Yilmaz E, Ersoy Y, Kazak E, Yildirmak MT, Kayaaslan B, Ozden K, Sener A, Kara A, Gunal O, Birengel S, Akbulut A, Yetkin F, Cuvalci NO, Sargin F, Pullukcu H, Gokengin D, Multicentric Hiv Study Group. Temporal trends in the epidemiology of HIV in Turkey. Curr HIV Res. 2020;18:258-66.

36. European Centre for Disease Prevention and Control/WHO Regional Office for Europe. Last Accessed Date: 18.09.2020. Available from: https:// www.ecdc.europa.eu/sites/default/files/documents/hiv-surveillancereport-2019.pdf

37. Wiseman AC. Immunosuppressive Medications. Clin J Am Soc Nephrol. 2016;11:332-43. 